\title{
Research Article \\ Determinant factors for giving the diphtheria, pertussis, and tetanus immunization in West Java Province 2017
}

Nur Hairunnisa ${ }^{1}$, Besral $^{2}$

Dikirim:

31 Desember 2018

Diterima

25 Februari 2019
Abstract

Purpose: DPT-HB immunization is one of the mandatory basic immunizations given to children to prevent diphtheria, pertussis (whooping cough) and tetanus. In 2017, West Java was one of the provinces that reported Diphtheria Outbreaks with 14 deaths from 153 cases. This study aims to determine the relationship of parental education, area of residence, visits to health care facilities and insurance ownership of the provision of DPT-HB Immunization in children in West Java Province. Method: The study design was cross sectional. The sample in this study was based on secondary children record data of the 2018 IDHS consisting of DPT-HB/Pentavalent immunization; parental education; residential area; visits to health care facilities and ownership of health insurance. Results: The results of this study were obtained between parental education ( $p$ value: 0,0001, OR: 2,084 ) and the area of residence ( $p$ value: 0,028, OR: 0,637 ) having a relationship with DPT-HB / Pentavalent immunization. Conclusion: Parental education has the strongest relationship with the provision of DPT-HB / Pentavalent immunization in children. Better education will have a positive effect on increasing knowledge and changing behavior in preventing infectious diseases such as by providing complete immunization to children.

Keywords: determinant factor; DPT Immunization - HB/Pentavalent; child

\footnotetext{
${ }^{1}$ Graduated Student of Public Health Science, Universitas Indonesia, Jakarta

${ }^{2}$ Biostaistic and Population Departement of Public Health Faculty, Universitas Indonesia, Jakarta
} 


\section{INTRODUCTION}

Immunization is a public health effort held in Indonesia since 1956. This program has proved effective and efficient successfully in Indonesia with being declared free of smallpox since 1974.Since 1977, immunization activities were expanded to become Immunization Development Programs (PPI) in the context of prevention of transmission against some Immunization Preventable Diseases (PD3I), namely Tuberculosis, Diphtheria, Pertussis, Measles, Polio, Tetanus, Hepatitis-B and Pneumonia (1).

Immunization in infants and children is one of the prevention and health maintenance efforts that will increase immunity when exposed to an illness. In Indonesia, every baby under one year must get complete basic immunization (2). DPT - HB is one of the mandatory immunizations that can prevent diphtheria, pertussis (whooping cough) and tetanus.

At the end of 2017, diphtheria outbreaks occurred in Yemen and Bangladesh, especially in refugee camps. 15 deaths were recorded from 804 cases of diphtheria between November 3 and December 12, 2017. According to the Ministry of Health data in 2017, Indonesia has 954 diphtheria spread in 170 districts / cities with 44 people dying, mortality or Case Fatality Rate (CFR) 4, 6\% is still lower than WHO's CFR Global around 5 - 10\% (3).

Basic Health Research in 2018 shows national coverage of Diphtheria, Pertussis, Tetanus and Hepatitis-B (DPT-HBHB) immunization at $61.3 \%$ and not immunization at $9.2 \%$ (4). The number of immunizations is still quite a lot, this certainly needs special attention from the Government. During the period from October to November 2017, there were 11 provinces that reported Diphtheria Outbreaks, one of which was West Java (5).

The case of diphtheria in West Java province was 153 cases with 14 people died (6). To prevent the spread of Diphtheria, the Government issued Regulation of the Minister of Health of the Republic of Indonesia Number 1501 / Menkes / Per / X / 2010 concerning Specific Types of Communicable Diseases, if 1 case of clinical diphtheria was found as an Outbreak and was required to carry out Outbreak Response Immunization (ORI). In the first phase of 2017 ORI carried out simultaneously in 3 provinces, namely DKI Jakarta, West Java and Banten.

West Java is one of the regions that carried out the Outbreak Response Immunization (ORI). ORI is the provision of additional immunity and repetition of previous immunizations. This is required for all age groups. The success of this immunization will certainly affect the status and degree of public health. Factors that influence the occurrence of disease according to Notoatmodjo (2007) among other social and habitual environments. The social environment is determined by several elements, namely education, employment, income and residence (7).
The role of parents is very important in providing complete immunization to children, so understanding the importance of immunization is very necessary. Knowledge, trust and health behavior of parents will certainly have an effect. Less socialization from health workers and the distance of healthcare facilities far from the area of residence causes low understanding and compliance of parents in immunization. So that promotive and preventive efforts have not run optimally (8).

Based on this background, due to the lack of immunization coverage, especially DPT-HB immunization, which is one of the reasons for the incidence and death in children tends to increase. Even infectious diseases such as diphtheria that were once reduced can reappear and result in death. For this reason, researchers want to know what factors are associated with administering DPT-HB immunization to children in the West Java Province.

\section{METHOD}

Data this study were based from the Indonesian Demographic and Health Survey in 2018. Subjects were individuals in West Java Province. The data on children contains immunization, parental education, areas of residence for visits to health care facilities and ownership of health insurance. The topic of the questionnaire used is part 5 (Child Immunization).

Based on the data obtained on the topic of child immunization, the independent variable used is parental education, the area of residence of visits to health service facilities and ownership of health insurance. The dependent variable used is the administration of DPT immunization - HB in children. However, there are two types of dummy used to represent the dependent variable used, namely Dummy DPT - HB and Pentavalent. This is done by considering the completeness of the data on each immunization variable.

\section{Operational definition}

The dependent variable is DPT-HB immunization and Pentavalent assumption that one of these variables is complete. The DPT-HB and Pentavalent vaccine is the same type of immunization, the difference is only in the trademark of the vaccine. The dummy variable is determined by 1 = if DPT Immunization - HB / Pentavalent; 0 = if not DPT Immunization - HB / Pentavalent.

Independent variables include: 1) Parental education is the last type of education from parents (respondents). The dummy variable is determined by $1=$ higher education; 0 = low education; 2) Residential Area, namely the residential residence area, which is divided into two categories, namely urban and rural areas. The dummy variable is determined by $1=$ Urban; 0 = Rural; 3 ) Visits to health care facilities, namely respondents visiting health care facilities in the past year. The dummy variable is 
determined by 1 = Yes; 0 = no; 4) Ownership of health insurance, namely respondents owning or becoming users of health insurance. The dummy variable is determined by 1 = Yes; 0 = no.

\section{Study Model}

This study is quantitative with a cross sectional design. Independent variables (parental education, area of residence, visits to health care facilities, ownership of health insurance) and dependent variables (DPT-HB / Pentavalent immunization). The study population is respondents who have children aged $\geq 1$ year who live in the West Java Region. This study sample uses total sampling, namely the entire population.

The data analysis method used in this study was gradually started by univariate analysis which described the characteristics of the study subjects which were then analyzed bivariate then continued with multivariate tests using logistic regression. This test is used to explain the

Table 1. Characteristics of study

\begin{tabular}{lcc}
\hline \multicolumn{1}{c}{ Variables } & Amount & $\begin{array}{c}\text { Percentage } \\
(\%)\end{array}$ \\
\hline $\begin{array}{l}\text { Provision of DPT-HB / Pentavalent } \\
\text { immunization }\end{array}$ & \\
$\quad$ Not immunization & 156 & 18,8 \\
$\quad$ Get immunization & 676 & 81,3 \\
\hline Parent Education & & \\
$\quad$ Low education & 215 & 25,8 \\
$\quad$ Higher education & 617 & 74,2 \\
\hline Residential Area & 651 & 78,2 \\
$\quad$ Urban & 181 & 21,8 \\
$\quad$ Rural & 297 & 35,7 \\
\hline Visit to Health Service Facilities & 535 & 64,3 \\
$\quad$ Not visiting & & \\
$\quad$ Visit & 322 & 38,7 \\
\hline Insurance Ownership & 510 & 61,3 \\
$\quad$ Do not have & 832 & 100 \\
$\quad$ Have insurance &
\end{tabular}

relationship between several independent variables with a dependent variable. The steps of this analysis start from bivariate analysis with criteria p value $\leq 0.25$ if $>0.25$, then it will not proceed to bivariate analysis.

After the bivariate analysis is done, the results can be continued to be analyzed again with multivariate analysis. This analysis uses logistic regression with the criteria $p$ value $\leq 0.05$, if it is greater it will be released in stages. After being issued, it is necessary to look at changes in OR (Exp), if it is greater than $10 \%$, then the variable is the confounding variable so that it is put back in the multivariate model.

\section{Statement of Ethics}

This study is a study with secondary data analysis. Therefore, there is no need for ethical approval in this study.

\section{RESULTS}

\section{Univariate analysis}

Before carrying out bivariate analysis, univariate analysis was used to analyze each study variable (respondent characteristics) descriptively. The study variables analyzed were independent variables, namely parents' education, residential area, visits to health care facilities and ownership of health insurance, dependent variables, namely DPT immunization - HB / Pentavalent immunization. The results of the study show that the frequency distribution of variables and dependent variables can be seen in Table 1 .

\section{Bivariate analysis}

Bivariate analysis was used to analyze the relationship of each study variable. The study variables analyzed were independent variables, namely the education of parents, the area of residence, visits to health care facilities and ownership of health insurance as well as the dependent variable, namely the administration of DPT immunization

Table 2. Independent Variable Relationship with Giving DPT-HB / Pentavalent Immunization in West Java Province 2017

\begin{tabular}{|c|c|c|c|c|c|c|c|c|}
\hline \multirow{3}{*}{$\begin{array}{l}\text { Independent Variables and } \\
\text { Categories }\end{array}$} & \multicolumn{6}{|c|}{ Giving DPT-HB/Pentavalent Immunization } & \multirow{3}{*}{ P Value } & \multirow{3}{*}{ OR } \\
\hline & \multicolumn{2}{|c|}{$\begin{array}{c}\text { No Immunization DPT-HB/ } \\
\text { Pentavalent }\end{array}$} & \multicolumn{2}{|c|}{$\begin{array}{c}\text { Receives DPT Immunization- } \\
\text { HB/Pentavalent }\end{array}$} & \multicolumn{2}{|c|}{ Total } & & \\
\hline & $\mathrm{N}$ & $\%$ & $\mathrm{~N}$ & $\%$ & $\mathrm{n}$ & $\%$ & & \\
\hline \multicolumn{9}{|l|}{ Parent Education } \\
\hline Low education & 62 & 28,8 & 153 & 71,2 & 215 & 100 & 0,001 & 2,255 \\
\hline Higher education & 94 & 15,2 & 523 & 84,8 & 617 & 100 & & \\
\hline Urban & 108 & 16,6 & 543 & 83,4 & 651 & 100 & 0,004 & 0,551 \\
\hline Rural & 48 & 26,5 & 133 & 73,5 & 181 & 100 & & \\
\hline \multicolumn{9}{|l|}{$\begin{array}{l}\text { Visit to Health Service Facilities } \\
\text { (Health Facilities) }\end{array}$} \\
\hline Not visiting & 58 & 19,5 & 239 & 80,5 & 297 & 100 & 0,711 & 1,082 \\
\hline Visit & 98 & 18,3 & 437 & 81,7 & 535 & 100 & & \\
\hline \multicolumn{9}{|l|}{ Insurance Ownership } \\
\hline Have insurance & 88 & 17,3 & 422 & 82,7 & 510 & 100 & & \\
\hline
\end{tabular}


Table 3. Independent Variable Bivariate Selection Results with DPT-HB / Pentavalent Immunization

\begin{tabular}{|c|c|c|c|}
\hline No & Independent Variable & P Value & Information \\
\hline 1 & Parent Education & 0,001 & $\begin{array}{l}\text { Enter the multivariate } \\
\text { model }\end{array}$ \\
\hline 2 & Residential Area & 0,004 & $\begin{array}{l}\text { Enter the multivariate } \\
\text { model }\end{array}$ \\
\hline 3 & $\begin{array}{l}\text { Visit Health Service } \\
\text { Facilities }\end{array}$ & 0,711 & $\begin{array}{l}\text { Not Enter the } \\
\text { multivariate model }\end{array}$ \\
\hline 4 & Insurance Ownership & 0,172 & $\begin{array}{l}\text { Enter the multivariate } \\
\text { model }\end{array}$ \\
\hline
\end{tabular}

Table 4. First Multivariate Modeling

\begin{tabular}{clcccc}
\hline & Variable & P Value & O R & \multicolumn{2}{c}{ 95 CI for Exp $\beta$} \\
\cline { 4 - 6 } & & Parent & Lower & Upper \\
\hline $\mathbf{2}$ & $\begin{array}{l}\text { Education } \\
\text { Residential } \\
\text { Area }\end{array}$ & 0,0001 & 2,070 & 1,421 & 3,014 \\
$\mathbf{3}$ & $\begin{array}{l}\text { Insurance } \\
\text { Ownership }\end{array}$ & 0,334 & 1,194 & 0,833 & 1,710 \\
\hline
\end{tabular}

Table 5. Second Multivariate Modeling

\begin{tabular}{|c|c|c|c|c|c|}
\hline \multirow{2}{*}{\multicolumn{2}{|c|}{ Variable }} & \multirow{2}{*}{ P Value } & \multirow{2}{*}{ O R } & \multicolumn{2}{|c|}{$95 \mathrm{CI}$ for $\operatorname{Exp} \beta$} \\
\hline & & & & Lower & Upper \\
\hline 1 & $\begin{array}{l}\text { Parent } \\
\text { Education }\end{array}$ & 0,0001 & 2.084 & 1,431 & 3,034 \\
\hline 2 & $\begin{array}{l}\text { Residential } \\
\text { Area }\end{array}$ & 0,028 & 0,637 & 0,427 & 0,952 \\
\hline
\end{tabular}

Table 6. Multivariate Modeling Results

\begin{tabular}{llccccc}
\hline & Variable & P Value & $\beta$ & O R & $95 \%$ CI for $\operatorname{Exp} \beta$ \\
\hline $\mathbf{1}$ & $\begin{array}{l}\text { Parent } \\
\text { Education }\end{array}$ & 0,0001 & 0,734 & 2,084 & 1,431 & 3,034 \\
$\mathbf{2}$ & $\begin{array}{l}\text { Residential } \\
\text { Area }\end{array}$ & 0,028 & $-0,450$ & 0,637 & 0,427 & 0,952 \\
\hline & & & & & \\
\hline
\end{tabular}

- HB / Pentavalent. Bivariate analysis used the chi square test because the independent and dependent variables were categorical.

From Table 2, the results of the statistical test variables found that the relationship of visits to health care facilities with DPT-HB / Pentavalent immunization was not significantly associated with a p value $=0.711>0.25$. While the education variables of parents, residential areas and insurance ownership have a $p$ value $\leq 0.25$ so that they can be included in multivariate modeling.

\section{Multivariate analysis}

The next step is multivariate modeling by entering the independent variables that can be included in the model with $\mathrm{p}$ value $\leq 0.25$ (Table 3 ).

\section{1st Multivariate Modeling}

Multivariate analysis was performed on 3 independent variables with DPT-HB / Pentavalent immunization, resulting in the 1st modeling analysis table (Table 4).
The first modeling results, the insurance ownership variable was obtained with a $\mathrm{p}$ value $=0.334>0.05$. So that the insurance ownership variable is excluded from multivariate modeling.

\section{2nd Multivariate Modeling}

Multivariate analysis was carried out on 2 independent variables with DPT-HB / Pentavalent immunization, resulting in the second modeling analysis Table 5.

The results of the second modeling found that the education variables of parents and residential areas had a $p$ value $<0.05$, while the insurance ownership variable had a $\mathrm{p}$ value $>0.05$. Insurance ownership variables are excluded from multivariate modeling.

From these results, the second multivariate modeling is the final modeling. The final modeling can be seen in Table 6.

Independent variables related to DPT-HB / Pentavalent immunization are as follows:

\section{Parent Education}

From the results of the analysis obtained $\mathrm{p}$ value $=0,0001$ with parents' education OR of 2,084 (95\% CI: 1,431-2,034) which means that highly educated parents risk 2 times giving DPT-HB / Pentavalent immunization to children compared to parents who low education.

Residential Area

From the analysis results obtained p value 0.028 with OR residential area of 0.637 (95\% CI: 0.427-0.952) which means respondents who live in urban areas are 0.6 times more at risk of DPT-HB / Pentavalent immunization than respondents who reside in rural areas.

Of the two variables that are most closely related are parents' education.

\section{DISCUSSION}

\section{Parent Education}

From the results of multivariate analysis of parental education and DPT immunization, the $\mathrm{p}$ value $=0,0001$ $(\mathrm{OR}=2,084)$ means that there is a significant relationship between the education of parents and DPT-HB / Pentavalent immunization. This result is in line with the research of Zuriatina (2018) that is obtained $p$ value $0,0001<0,05$ which means that there is a meaningful relationship between education and the completeness of basic immunization in children under five (9). This can be interpreted that the higher the level of education of parents, the greater the proportion of complete immunization. Parents who are highly educated will be better at receiving and understanding about disease prevention so that they have a higher awareness than parents with low education. This awareness encourages parents to immunize their children (10).

The basic concept of education is a learning process towards better change in oneself, family and society. 
Education is very important in influencing knowledge. Individuals who have a high level of education tend to be easier to receive information, ideas or new ideas such as information about immunization by health workers, while those with low education are more difficult to receive such information. So that education is very influential in making decisions in giving immunizations to children (11).

Health education can also help parents improve behavior in obtaining optimal health degrees. The level of education and knowledge of parents greatly influences the implementation of immunization activities such as DPT-HB immunization in children. Parents with high knowledge about immunization will then provide complete basic immunization to their children and pay attention to when the right time to provide these immunizations.

Conversely, parents who have low knowledge will not know the importance of giving immunization to children. Therefore, actions need to be taken such as counseling health workers both in the Puskesmas, Posyandu individually and in groups. Other counseling that can be done is by distributing leaflets, posters or other social media (11).

The results of this study are also in line with the theory in Notoatmodjo (2012), namely education is a form of intervention that is given to improve the ability to think and receive information correctly including health information. Education has a very positive effect on increasing capacity in changing disease prevention behaviors such as immunizing children (12).

\section{Residential Area}

From the results of multivariate analysis of the area of residence and administration of DPT-HB / Pentavalent Immunization, the $\mathrm{p}$ value $=0.028(\mathrm{OR}=0.637)$ was obtained. This result is in line with Nurani (2013) research, which is obtained by the results of the chi square test with $p$ value $0.026<0.05$, which means there is a relationship between the access to housing and giving immunization to children (13). From these results, it can be seen that ease of access is one factor for visiting health services.
Urban areas are more affordable and easier to get access to immunization for children than rural areas. Communities with affordable housing are willing to give immunizations to children as much as $49.1 \%$ less than those who are unwilling at $69.2 \%$ (7).

The results of this study are in line with the theory in Bustami (2011) that to improve quality in health services is not permitted health services are hindered by geographical conditions such as transportation, region, distance and time of travel. Health services such as providing immunization to children should be able to be carried out well and evenly if access to health services such as posyandu or auxiliary health centers can be increased or increased to achieve regional achievements by regenerating health workers or counseling the community that immunization is important and not expensive so her children (14).

\section{LIMITATIONS}

The limitation in this study is that not all variables in the data can be analyzed, such as the age of the mother and access to information about immunization. In addition there are still selection bias such as sampling errors within the boundaries and locations of the study population. Selection bias occurs when studies use different criteria in the study subject selection procedure (15).

\section{CONCLUSION}

Based on the description above it can be concluded that there is a relationship between the education of parents and the area of residence with the provision of DPTHB / Pentavalent immunization in children in the West Java Region in 2017. Parents' education variables have the strongest relationship with DPT-HB immunization / Pentavalent in children with $\mathrm{OR}=2,084$ which means that respondents who are highly educated 2,084 times greater give DPT-HB / Pentavalent immunization in children than respondents who have low education in West Java Region 2017. 


\begin{abstract}
Abstrak
Tujuan: Imunisasi DPT-HB merupakan salah satu imunisasi dasar wajib yang diberikan pada anak untuk mencegah penyakit difteri, pertusis (batuk rejan) dan tetanus. Tahun 2017, Jawa Barat merupakan salah satu provinsi yang melaporkan KLB Difteri dengan jumlah kematian 14 orang dari 153 kasus. Studi ini bertujuan untuk mengetahui hubungan pendidikan orang tua, wilayah tempat tinggal, kunjungan ke fasilitas pelayanan kesehatan dan kepemilikan asuransi terhadap pemberian Imunisasi DPT-HB pada anak di Provinsi Jawa Barat. Metode: Desain studi adalah cross sectional. Sampel dalam studi ini berdasarkan data sekunder children record SDKI tahun 2018 terdiri dari pemberian imunisasi DPT-HB/Pentavalen; pendidikan orang tua; wilayah tempat tinggal; kunjungan ke fasilitas pelayanan kesehatan dan kepemilikan asuransi kesehatan. Hasil: Hasil studi ini didapatkan antara pendidikan orang tua ( $p$ value: 0,0001, OR: 2,084) dan wilayah tempat tinggal (p value: 0,028, OR: 0,637) memiliki hubungan dengan pemberian imunisasi DPT-HB/ Pentavalen. Simpulan: Pendidikan orang tua memiliki hubungan yang paling kuat dengan pemberian imunisasi DPTHB/Pentavalen pada anak. Pendidikan yang semakin baik akan berpengaruh positif terhadap peningkatan pengetahuan serta perubahan perilaku dalam mencegah penyakit menular seperti dengan memberikan imunisasi lengkap pada anak.
\end{abstract}

Kata Kunci: faktor Determinan; imunisasi DPT-HB/pentavalen; anak

\section{REFERENCES}

1. Pusat Pendidikan dan Pelatihan Tenaga Kesehatan KK. BUKU AJAR IMUNISASI. 2014. 2 p.

2. Kesehatan $\mathrm{K}$, Indonesia R, Kesehatan K. Berikan anak imunisasi rutin lengkap, ini rinciannya. 2018;1-2.

3. www.searo.who.int. Situasi Difteri di Dunia dan Indonesia. 2017.

4. Badan Penelitian dan Pengembangan Kesehatan. RISKESDAS_LAUNCHING_301018_edit271018_nowo_ Edit Kaban_01-1. 2018.

5. Wabah difteri di 20 provinsi: Lima hal yang perlu anda ketahui - BBC News Indonesia [Internet]. [cited 2018 Nov 23]. Available from: https://www.bbc.com/ indonesia/amp/majalah-42215042

6. 14 Orang Meninggal akibat Difteri di Jawa Barat- Kompas.com [Internet]. [cited 2018 Nov 23]. Available from: https://regional.kompas.com/ $\mathrm{read} / 2017 / 12 / 15 / 08124791 / 14$-orang-meninggalakibat-difteri-di-jawa-barat

7. Bulan A, Kecamatan DI, Dan K, Izza N, Lestari D. Factor of Parents and DPT Immunization Status in Ketapang and Sokobanah Sub District, Sampang District. 2017; (17):43-51.
8. Triana V. Faktor yang Berhubungan dengan Pemberian Imunisasi Dasar Lengkap pada Bayi Tahun 2015. J Kesehat Masy Andalas. 2016;Vol 10, No:123-35.

9. Zuriatina C.N, Rahayu H. Faktor-Faktor yang Berhubungan dengan Kelengkapan Imunisasi Dasar pada Batita di Desa Hutaimbaru Kecamatan Halongonan Kabupaten Padang Lawas Utara Tahun 2016. 2016;3(1).

10. Budiman AR. Kapita Selekta Kuesioner Pengetahuan dan Sikap dalam Penelitian. In Jakarta: Salemba Medika; 2014.

11. Adzaniyah Isyani Rahmawati CUW. Faktor yang Mempengaruhi Kelengkapan Imunisasi Dasar di Kelurahan Krembangan Utara. J Berk Epidemiol. 2014;Vol 2, No.

12. Notoatmodjo S. Promosi Kesehatan dan Perilaku Kesehatan. Revisi. Jakarta: Rineka Cipta; 2012.

13. Nurani VA. Faktor-Faktor yang Berhubungan dengan Kelengkapan Imunisasi Dasar Pada Bayi di Desa Truko Kecamatan Kangkung Kabupaten Kendal Tahun 2013. Semarang; 2013.

14. Bustami. Penjaminan Mutu Pelayanan Kesehatan dan Akseptabilitasnya. Rina Astikawati PA, editor. Padang: Erlangga; 2011.

15. Gede W, Eka A, Sutarga M. Tutorial Kesalahan Sitematik (Bias) dan Cara Penanggulangannya : 1-13. 